\title{
INHA LT
}

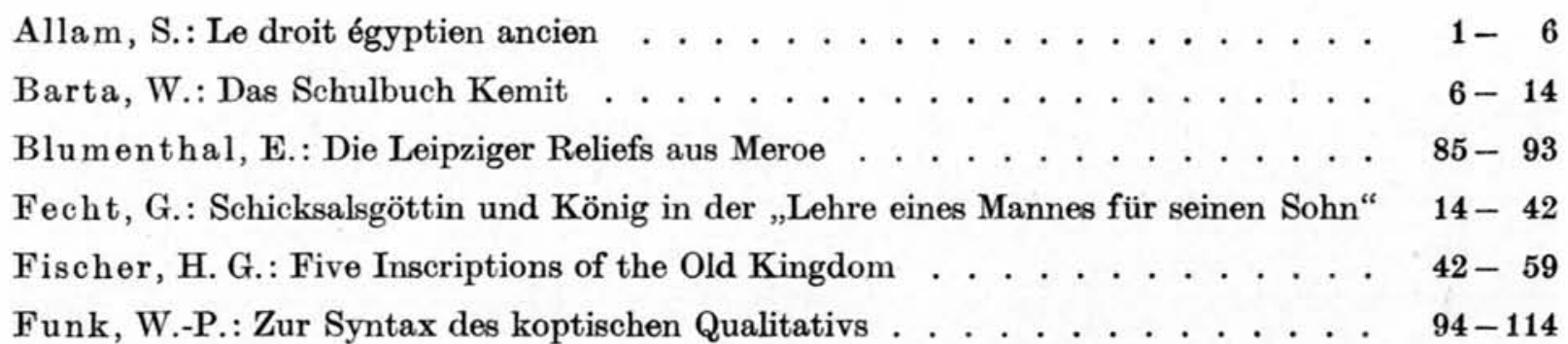

Grunert, St.: Zum Eherecht im ptolemäischen Ägypten nach den demotischen Papyri . . . . . . . . . . . . . . . . . 114-122

Hornung, E.: Struktur und Entwicklung der Gräber im Tal der Könige. . . . . . 5 59-66

Kemp, B. J.: The Harim-Palace at Medinet el-Ghurab . . . . . . . . . . . . . 122-133

Reineke, W. F.: Gedanken zum vermutlichen Alter der mathematischen Kenntnisse im Alten Ägypten. . . . . . . . . . . . . . . . . . . . . . . . . 67- 76

Schenke, H.-M.: Zum sogenannten Tractatus Tripartitus des Codex Jung . . . . . 133-141

Spalinger, A.: The Reign of King Chabbash: An Interpretation . . . . . . . . . 142-154

Staehelin, E.: Zur Hathorsymbolik in der ägyptischen Kleinkunst . . . . . . . 76-84

Verner, M.: Excavations at Abusir. Season 1976. Preliminary Report . . . . . . 155-159

Miszelle:

Guilmot, M.: Une stèle inédite de Neb-Imen . . . . . . . . . . . . . . . . . 160 